\title{
European grassland ecosystems: threatened hotspots of biodiversity
}

\author{
Jan Christian Habel • Jürgen Dengler • Monika Janišová • \\ Péter Török · Camilla Wellstein • Michal Wiezik
}

Published online: 21 August 2013

(C) Springer Science+Business Media Dordrecht 2013

\begin{abstract}
Biodiversity is not homogenously distributed over the globe, and ecosystems differ strongly in the number of species they provide. With this special issue we highlight the ecology and endangerment of one of the most diverse ecosystem of Europe: the European grassland ecosystems. The selected 16 contributions describe interactions from below-ground to the atmosphere and focus on (1) effects of abiotic and biotic on species diversity, (2) the impact of various factors along spatial and temporal gradients, (3) the
\end{abstract}

J. C. Habel $(\bowtie)$

Department of Ecology and Ecosystem Management, Technische Universität München,

Hans-Carl-von-Carlowitz-Platz 2, 85350 Freising-Weihenstephan, Germany

e-mail: Janchristianhabel@gmx.de

J. Dengler

Disturbance Ecology, Bayreuth Center of Ecology and Environmental Research (BayCEER),

University of Bayreuth, 95447 Bayreuth, Germany

J. Dengler

Synthesis Centre (sDiv), German Centre for Integrative Biodiversity Research (iDiv)

Halle-Jena-Leipzig, 04103 Leipzig, Germany

J. Dengler

Biodiversity, Evolution and Ecology of Plants (BEE), Biocenter Klein Flottbek and Botanical Garden,

University of Hamburg, 22609 Hamburg, Germany

M. Janišová

Institute of Botany, Slovak Academy of Sciences, 97411 Banská Bystrica, Slovakia

P. Török

Department of Ecology, University of Debrecen, 4032 Debrecen, Hungary

P. Török

DE-MTA Biodiversity and Ecosystem Services Research Group, University of Debrecen, 4032 Debrecen, Hungary

C. Wellstein

Biogeography, Bayreuth Center of Ecology and Environmental Research (BayCEER),

University of Bayreuth, 95447 Bayreuth, Germany 
relevance of falling abandoned and eutrophication-including countervailing management strategies like encroachment; and (4) intraspecific effects based on physiology, genetics and intraspecific plasticity. The contributions cover fungi, plants, and invertebrates and highlight effects taking place at the level of ecosystem, species community, species, populations, and also within individuals (physiology and genetics).

Keywords Abandonment - Animal assemblage - Conservation management . Diversity hotspot $\cdot$ Eutrophication $\cdot$ Plant community $\cdot$ Species richness

Why biodiversity is not homogenously distributed across the globe, but concentrated in certain regions, has fascinated biologists for centuries and has been the inspiration and focus of key ecological and evolutionary theories (Darwin 1859; Wallace 1860; Briggs 1988; Wiley 1988; Gaston 2001; Mutke and Barthlott 2005). For most taxa, species richness increases from the poles towards the equator. Also, regions covering long altitudinal gradients leading to high topographic and climatic heterogeneity (Possingham and Wilson 2005), as well as regions consisting of numerous true or habitat islands that stimulated speciation through isolation are prone to extraordinary species richness, as is the case of the Eastern Afromontane "mountain archipelago" along the Great Rift or the IndoMalay biodiversity hotspot (Mittermeier et al. 2011). Thirty-five such biodiversity hotspots are recognised worldwide, all by extremely high levels of endemism and threat $(>1,500$ endemic vascular plants and $>70 \%$ of the natural vegetation being destroyed; Mittermeier et al. 2011). Europe has a major share in only one of these hotspots, the Mediterranean Basin (cf. Hewitt 2011). This region is characterised by long-term isolation of the biota, which is often restricted to one of the various island and peninsulas, which are separated by sea and/or hardly surmountable mountain barriers (e.g. the Alps, Pyrenees, Carpathians). Long-term isolation accompanied by relatively constant climatic conditions has led to the accumulation of species in southern Europe over the past millions of years, while temperate and northern Europe are characterised by biodiversity impoverishment in consequence of the glaciation cycles with subsequent range retraction-expansion dynamics of species including extinction processes (Thompson 2005; Schmitt 2007; Habel et al. 2009).

While being relatively species-poor at larger spatial scales, temperate Europe comprises certain habitats with extreme species richness at small scales, in particular the semi-natural grasslands. Recently, it has been shown that European semi-dry basiphilous grasslands exceed any other ecosystem of the world including tropical rainforests with regard to vascular plant species richness for grain sizes $<100 \mathrm{~m}^{2}$ (Dengler et al. 2012; Wilson et al. 2012). Among Europe's endemic vascular plants, $18.1 \%$ are bound to grassland habitats, nearly twice as many as in forests, despite the latter covering much more land area (Hobohm and Bruchmann 2009). Also, for many other taxa, the semi-natural grasslands host many more species than expected from their spatial extent, for example more than two-thirds of the butterflies (WallisDeVries and van Swaay 2009). While grasslands constitute the natural vegetation of the steppe biome in Eastern Europe (Bohn et al. 2004), they largely result from the activities of humans and their livestock (e.g. grazing, mowing, burning) in areas actually humid enough to allow tree growth (Ellenberg and Leuschner 2010; Vrahnakis et al. in

C. Wellstein

Faculty of Science and Technology, Free University of Bozen-Bolzano, 39100 Bozen, Italy

M. Wiezik

Department of Applied Ecology, Technical University, 96053 Zvolen, Slovakia 
press). Thus grasslands became widely distributed over Europe since the Anthropocene (Poschlod and WallisDeVries 2002; Poschlod et al. 2009; Hájková et al. 2011).

During millennia of low-intensity land use, grasslands accumulated a huge amount of biodiversity. Today, many of the European grassland ecosystems of high conservation value are threatened by a change of the very land use that formerly created and maintained them, i.e. intensification, abandonment, afforestation, or transformation of arable fields (WallisDeVries et al. 2002; Öckinger et al. 2006; Veen et al. 2009; Valkó et al. 2012). Further sources of threat include eutrophication through airborne nitrogen deposition, and in some cases biotic invasions. While these phenomena are well-known issues (e.g. Janišová et al. 2011), we still urgently need a better understanding of mechanisms behind the patterns of biodiversity at different levels (cross-taxonomic, taxonomic, functional, genetic) and spatial scales in European grasslands. Such knowledge at the same time is a prerequisite for projecting the biotas' and systems' response to future environmental changes and for conservation.

With this Special Issue on "Biodiversity of European grasslands" we emphasise the outstanding richness of this biodiversity hotspot, while at the same time stressing its alarming endangerment. This Special Issue was initiated at the 8th European Dry Grassland Meeting, 13-17 June 2011, in Uman', Ukraine, but in addition to conference contributions some invited articles have been included. Two further special Features in international journals will appear in parallel and complement the present volume: a special issue of Agriculture, Ecosystems and Environment (eds. Dengler et al.) will deal specifically with botanical diversity in Palaearctic grasslands, while a just started virtual special feature of Applied Vegetation Science addresses the diversity and large-scale classification of grassland plant communities, looking at the community-level diversity (Dengler et al. 2013). Information on the organiser of all three special features, the European Dry Grassland Group (EDGG), can be found in Vrahnakis et al. (in press) and in the Infobox.

\section{Infobox: The European Dry Grassland Group (EDGG)}

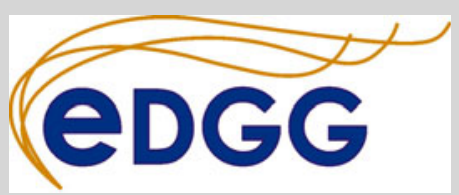

The European Dry Grassland Group (EDGG; http://www.edgg.org) was founded in 2008 as a successor of the German Arbeitsgruppe Trockenrasen and became an official working group of the International Association for Vegetation Science (IAVS; http://www.iavs.org) in 2009. As of 10 June 2013, EDGG had 945 members from 58 countries, including zoologists and botanists as well as scientists and conservation practitioners. Membership in EDGG is free of charge and its activities include:

- Organisation of annual conferences and research expeditions.

- Publication of the quarterly open-access Bulletin of the European Dry Grassland Group.

- Organisation of Special Features in international journals.

- Knowledge collection on dry grassland, such as vegetation-plot databases and best practice examples in conservation and management.

- Influencing relevant national and European policies by informing policy makers, promoting petitions etc. 
This array of 16 contributions covers plants, fungi, and invertebrates, and highlights effects taking place at the level of ecosystem, species community, species, populations, and also individuals (physiology and genetics). In the following, we summarise the contributors' findings under the following categories: (1) effects of abiotic (habitat size, isolation, topography, soil, and biotic (vegetation structure) factors on species diversity; (2) gradients over space and time (including the biogeographical history as well as management changes during the past decades); (3) the relevance of falling abandoned, eutrophication-including countervailing management strategies like encroachment; and (4) intraspecific effects (physiology, genetics and intraspecific plasticity) related to species and habitat qualities.

\section{Effects of abiotic and biotic factors on species diversity}

The impact of abiotic and biotic factors on the composition of species assemblages (abundance and species richness) are of major interest in conservation ecology. Fragmentation and habitat isolation are interpreted as main drivers determining the composition of species assemblages (first highlighted in the theory of island biogeography by MacArthur and Wilson in 1967. In the first contribution, Horváth et al. (2013) showed no significant correlation between habitat size and isolation on spider species richness, but on those species' assemblages: while isolated and small habitat fragments are dominated by generalists, specialists (adapted on sand) accumulate in rather large and high quality habitat patches. In addition to habitat size and isolation, the topography of the landscape may have a direct impact on species composition and richness. This is shown for plant species composition, richness and the functional composition over 258 grassland plots (Moeslund et al. 2013). This is further supported by a study on grasshoppers: south-facing pastures maintained a greater Orthoptera diversity than north facing pastures (Weiss et al. 2013); The authors further highlight that abundance is positively correlated with bare ground (and in consequence grazing might be better than mowing).

Apart from habitat size, isolation and/or landscape structure (like topography, see above), habitat quality (of both the particular habitat and the surrounding habitats) strongly influences the occurrence of species, and thus the species composition and diversity, as first demonstrated for the butterfly Coenonympha tullia (Dennis and Eales 1997). For example the composition of plant species in wet grasslands is strongly affected by various abiotic factors like chemical parameters of the soil, climatic conditions and human impact (Zelnik and Čarni 2013). In a study on Arbuscular Mycorrhizal Fungi (AMF), effects of land use, host plant neighbourhood and spatial arrangement on the AMF composition was tested over 67 grassland plots spread across the three German Biodiversity Exploratories (Morris et al. 2013). The authors show that the diversity of AMF react similar sensitive at both, large- and small scales; for example, the ability of AMF to provide protection from pathogens declined under high land-use intensity (Morris et al. 2013).

\section{Temporal and spatial gradients}

The floristic composition of plant communities is strongly influenced by biogeographic history; this is shown for the Dinaric versus Central-European region, both representing different biogeographical realms (Pipenbaher et al. 2013). The authors explain the relevance of biogeographic history for the observed strong differences in floristic and functional composition of dry grassland communities. However, the processes leading to rarity 
in these grasslands were similar for both areas. A second contribution studying a temporal gradient highlights the effects of recent habitat transformations during the past decades, from 1970 until today (Filz et al. 2013). The authors showed that species composition changed from the past to present towards a generalist-species dominated community, despite habitat management activities, and they explain this trend by external factors as eutrophication and climate change. The following two contributions study effects along spatial gradients. Albrecht and Haider (2013) analyse effects of urbanisation (one of the main reason for decreasing grassland habitats) along a spatio-temporal urbanisation gradient from traditionally managed to urban developments. Area and diversity of traditional calcareous grasslands strongly decreased due to urbanisation; nevertheless, urban habitats support a specific group of endangered species. Species richness of 11 invertebrate taxa showed a bimodal response pattern along a transect from pine plantation to short grass steppe, with a peak of species richness at the habitat edge as well as in the grassland interior (Bieringer et al. 2013).

\section{Abandonment, eutrophication, and habitat management}

Abandonment and eutrophication are the main problems facing open and oligotrophic grasslands. Re-cutting of abandoned grassland significantly diminished the living biomass of dominant grasses increasing thus plant species diversity by facilitating establishment of less competitive species as shown in studies on grasslands of the Mediterranean Basin (Bonanomi et al. 2013). However, the nitrogen enrichment at levels comparable to atmospheric deposition hampered the positive effects of grassland management. Contrastingly, abandoned grasslands were more species-rich than managed ones; moreover they harboured distinct assemblages and more grassland specialist species (Wiezik et al. 2013). The restoration of formerly intact grasslands showed positive effects on Orthoptera assemblages over time (Rácz et al. 2013). The authors showed that species richness doubled and abundance increased almost ten-fold in the restored grasslands 4 years after restoration. The relevance of scale dependence was highlighted by Lauterbach et al. (2013). Effects of abandonment, eutrophication and habitat fragmentation were strongly scale-dependent: eutrophication and habitat loss had more marked effects on a regional scale, but habitat fragmentation may be the main driver of species threat on the local scale.

\section{Effects on the intraspecific level}

The three final contributions highlight the impact of intraspecific processes (physiology and genetics) of organisms living in grassland habitats. The contribution of Wellstein et al. (2013) demonstrates that the intraspecific trait variation of four grassland plants along with abiotic environmental variation shows a significant phenotypic adaptation to diverging environmental conditions. A second review incorporating 28 studies (20 species, 224 traits, including genetic, vegetative and reproductive traits) showed that various grassland management regimes affect the selection pressure in plants differently (Pluess 2013). The third and last work highlights the effect of species' ecology on the genetics in grassland butterflies (Habel et al. 2013a). The authors found that generalist species with wide distributions and high abundances show rather high genetic diversity accompanied by low genetic differentiation, while species with specific habitat demands are characterised by comparatively low 
genetic diversities and high genetic differentiation. These patterns strongly mirror the distribution pattern due to their ecology and opposite population feature.

We hope that this Special Issue on European grasslands strongly contributes to a better understanding of ecosystem and species interactions, potential changes along spatial and temporal gradients, and scale-dependent effects-from molecule to ecosystem level and help to conserve this fascinating ecosystem hotspot in the future. Therefore we close this special issue with translating our mostly theoretical findings into practical advice (Habel et al. 2013b).

Acknowledgments We are grateful to the authors for their contributions and to all reviewers for their valuable comments on the manuscripts of this Special Issue.

\section{References}

Albrecht H, Haider S (2013) Species diversity and life history traits in calcareous grasslands vary along an urbanization gradient. Biodivers Conserv. doi:10.1007/s10531-013-0437-0

Bieringer G, Zulka KP, Milasowszky N, Sauberer N (2013) Edge effect of a pine plantation reduces dry grassland invertebrate species richness. Biodivers Conserv. doi:10.1007/s10531-013-0435-2

Bohn U, Gollub G, Hettwer C, Neuhäuslová Z, Raus T, Schlüter H, Weber H, Hennekens S (eds) (2004) Map of the natural vegetation of Europe. Scale 1:2500000. Interactive CD-ROM: explanatory text, legend, maps [CD ROM+booklet]. Bundesamt für Naturschutz, Bonn

Bonanomi G, Incerti G, Allegrezza M (2013) Plant diversity in Mediterranean grasslands: the controlling effect of land abandonment, nitrogen enrichment and fairy ring fungi. Biodivers Conserv. doi:10.1007/ s10531-013-0502-8

Briggs JC (1988) Biogeography and plate tectonics—developments in paleontology and stratigraphy. Elsevier, Amsterdam

Darwin C (1859) On the origin of species by means of natural selection, or, the preservation of favoured races in the struggle for life. John Murray, London

Dengler J, Becker T, Ruprecht E, Szabó A, Becker U, Beldean M, Bita-Nicolae C, Dolnik C, Goia I, Peyrat J, Sutcliffe LME, Turtureanu PD, Uğurlu E (2012) Festuco-Brometea communities of the Transylvanian Plateau (Romania): a preliminary overview on syntaxonomy, ecology, and biodiversity. Tuexenia 32:319-359

Dengler J, Bergmeier E, Willner W, Chytrý M (2013) Towards a consistent classification of European grasslands. Appl Veg Sci 16:518-520

Dennis RLH, Eales HT (1997) Patch occupancy in Coenonympha tullia (Muller, 1764) (Lepidoptera: Satyrinae): habitat quality matters as much as patch size and isolation. J Insect Conserv 1:167-176

Ellenberg H, Leuschner C (2010) Vegetation Mitteleuropas mit den Alpen in ökologischer, dynamischer und historischer Sicht, 6th edn. Ulmer, Stuttgart

Filz KJ, Engler JO, Stoffels J, Weitzel M, Schmitt T (2013) Missing the target? A critical view on butterfly conservation efforts on calcareous grasslands in south-western Germany. Biodivers Conserv. doi:10. 1007/s10531-012-0413-0

Gaston KJ (2001) Global patterns in biodiversity. Nature 405:220-227

Habel JC, Drees C, Schmitt T, Assmann T (2009) Refugial areas and postglacial colonizations in the Western Palearctic. In: Habel JC, Assmann T (eds) Relict species: phylogeography and conservation biology. Springer, Heidelberg, pp 189-197

Habel JC, Rödder D, Lens L, Schmitt T (2013a) The genetic signature of ecologically different grassland Lepidopterans. Biodivers Conserv. doi:10.1007/s10531-012-0407-y

Habel JC, Gossner MM, Meyer S, Eggermont H, Lens L, Dengler J, Weisser WW (2013b) Mind the gaps when using science to address conservation concerns. Biodivers Conserv. doi:10.1007/s10531-0130536-y

Hájková P, Roleček J, Hájek M, Horsák M, Fajmon K, Polák M, Jamrichová E (2011) Prehistoric origin of the extremely species-rich semi-dry grasslands in the Bílé Karpaty Mts (Czech Republic and Slovakia). Preslia 83:185-204

Hewitt GM (2011) Mediterranean Peninsulas: the evolution of hotspots. In: Zachos FE, Habel JC (eds) Biodiversity hotspots: distribution and protection of conservation priority areas. Springer, Heidelberg, pp 123-147 
Hobohm C, Bruchmann I (2009) Endemische Gefäßpflanzen und ihre Habitate in Europa: Plädoyer für den Schutz der Grasland-Ökosysteme. Ber Reinhold-Tüxen-Ges 21:142-161

Horváth R, Magura T, Szinetár C, Eichardt J, Tóthmérész B (2013) Large and least isolated fragments preserve habitat specialist spiders best in dry sandy grasslands in Hungary. Biodivers Conserv. doi:10. 1007/s10531-013-0439-y

Janišová M, Bartha S, Kiehl K, Dengler J (2011) Advances in the conservation of dry grasslands: introduction to contributions from the seventh European Dry Grassland Meeting. Plant Biosyst 145:507-513

Lauterbach D, Römermann C, Jeltsch F, Ristow M (2013) Factors driving plant rarity in dry grasslands on different spatial scales: a functional trait approach. Biodivers Conserv. doi:10.1007/s10531-013-0455-y

MacArthur RH, Wilson EO (1967) The theory of island biogeography. Princeton University Press, Princeton

Mittermeier RA, Turner WR, Larsen FW, Brooks TM, Gascon C (2011) Global biodiversity conservation: the critical role of hotspots. In: Zachos FE, Habel JC (eds) Biodiversity hotspots: distribution and protection of conservation priority areas. Springer, Heidelberg, pp 2-22

Moeslund JE, Arge L, Bøcher PK, Dalgaard T, Ejrnæs R, Odgaard MV, Svenning J-C (2013) Topographically controlled soil moisture drives plant diversity patterns within grasslands. Biodivers Conserv. doi:10.1007/s10531-013-0442-3

Morris EK, Buscot F, Herbst C, Meiners T, Obermaier E, Wäschke NW, Wubet T, Rillig MC (2013) Land use and host neighbor identity effects on arbuscular mycorrhizal fungal community composition in focal plant rhizosphere. Biodivers Conserv. doi:10.1007/s10531-013-0527-z

Mutke J, Barthlott W (2005) Patterns of vascular plant diversity at continental to global scales. Biol Skr 55:521-531

Öckinger E, Eriksson AK, Smith HG (2006) Effects of grassland abandonment, restoration and management on butterflies and vascular plants. Biol Conserv 133:291-300

Pipenbaher N, Kaligarič M, Mason NWH, Škornik S (2013) Dry calcareous grasslands from two neighboring biogeographic regions: relationship between plant traits and rarity. Biodivers Conserv. doi:10. $1007 / \mathrm{s} 10531-013-0520-6$

Pluess AR (2013) Meta-analysis reveals microevolution in grassland plant species under contrasting management. Biodivers Conserv

Poschlod P, WallisDeVries MF (2002) The historical and socioeconomic perspective of calcareous grasslands: lessons from the distant and recent past. Biol Conserv 104:361-376

Poschlod P, Baumann A, Karlík P (2009) Origin and development of grasslands in Central Europe. In: Veen P, Jefferson R, de Smidt J, van der Straaten J (eds) Grasslands in Europe of high nature value. KNNV Publishing, Zeist, pp 15-26

Possingham HP, Wilson KA (2005) Turning up the heat on hotspots. Nature 436:919-920

Rácz IA, Déri E, Kisfali M, Batiz Z, Varga K, Szabó G, Lengyel S (2013) Early changes of Orthopteran assemblages after grassland restoration: a comparison of space-for-time substitution versus repeated measures monitoring. Biodivers Conserv. doi:10.1007/s10531-013-0466-8

Schmitt T (2007) Molecular biogeography of Europe: Pleistocene cycles and postglacial trends. Front Zool 4:11

Thompson JD (2005) Plant evolution in the Mediterranean. Oxford University Press, New York

Valkó O, Török P, Matus G, Tóthmérész B (2012) Is regular mowing the most appropriate and cost-effective management maintaining diversity and biomass of target forbs in mountain hay meadows? Flora 207:303-309

Veen P, Jefferson R, de Smidt J, van der Straaten J (eds) (2009) Grasslands in Europe of high nature value. KNNV Publishing, Zeist

Vrahnakis MS, Janišová M, Rūsinga S, Török P, Venn S, Dengler J (in press): The European Dry Grassland Group (EDGG): stewarding Europe's most diverse habitat type. In: Baumbach H, Pfützenreuter S (eds) Steppenlebensräume Europas: Gefährdung, Erhaltungsmaßnahmen und Schutz. Thüringer Ministerium für Landwirtschaft, Forsten, Umwelt und Naturschutz, Erfurt

Wallace AR (1860) On the zoological geography of the Malay archipelago. Biol J Linn Soc 4:172-184

WallisDeVries MF, van Swaay CAM (2009) Grasslands as habitats for butterflies in Europe. In: Veen P, Jefferson R, de Smidt J, van der Straaten J (eds) Grasslands in Europe of high nature value. KNNV Publishing, Zeist, pp 27-34

WallisDeVries MF, Poschlod P, Willems JH (2002) Challenges for the conservation of calcareous grasslands in north-western Europe: integrating the requirements of flora and fauna. Biol Conserv 104:265-273

Weiss N, Zucchi H, Hochkirch A (2013) The effects of grassland management and aspect on Orthoptera diversity and abundance: site conditions are as important as management. Biodivers Conserv. doi:10. 1007/s10531-012-0398-8

Wellstein C, Chelli S, Campetella G, Bartha S, Galiè M, Spada F, Canullo R (2013) Intraspecific phenotypic variability of plant functional traits in contrasting mountain grasslands habitats. Biodivers Conserv. doi:10.1007/s10531-013-0484-6 
Wiezik M, Svitok M, Wieziková A, Dovčiak M (2013) Shrub encroachment alters composition and diversity of ant communities in abandoned grasslands of western Carpathians. Biodivers Conserv. doi:10.1007/ s10531-013-0446-z

Wiley EO (1988) Vicariance biogeography. Annu Rev Ecol Syst 19:513-542

Wilson JB, Peet RK, Dengler J, Pärtel M (2012) Plant species richness: the world records. J Veg Sci 23:796-802

Zelnik I, Čarni A (2013) Plant species diversity and composition of wet grasslands in relation to environmental factors. Biodivers Conserv. doi:10.1007/s10531-013-0448-x 